Tarbawy : Jurnal Pendidikan Islam

ISSN : 2407-4462 (Cetak), 2614-5812 (Elektronik)

Vol.8, No.1, 2021, Hal. 7-12

DOI: https://doi.org/ 10.32923/tarbawy.v8i1.1491

\title{
Upaya Orang Tua Untuk Meningkatkan Minat Remaja Dalam Mengikuti Kajian Majelis Ilmu Di Masjid Nurul Iman Desa Payabenua
}

\author{
Annisa Lestari ${ }^{1}$, Ela Isnani Munawwaroh ${ }^{2}$, Nadia Novianti ${ }^{3}$, Natikoh $^{4}$, Randu Abdi \\ Cahyadi $^{5}$
}

${ }^{1}$ IAIN Syaikh Abdurrahman Siddik Bangka Belitung

${ }^{2}$ IAIN Syaikh Abdurrahman Siddik Bangka Belitung

${ }^{3}$ IAIN Syaikh Abdurrahman Siddik Bangka Belitung

${ }^{4}$ IAIN Syaikh Abdurrahman Siddik Bangka Belitung

${ }^{5}$ IAIN Syaikh Abdurrahman Siddik Bangka Belitung

Info Artikel :

Diterima

Direvisi

Dipublikasikan

\section{Kata Kunci: \\ Minat \\ Remaja \\ Majelis Ilmu}

\begin{abstract}
ABSTRAK
Di desa Payabenua terdapat beberapa majelis ilmu, salah satunya majelis ilmu yang dilaksanakan di Masjid Nurul Iman setiap malam senin. Pengajian tersebut pada awalnya diikuti oleh beberapa kalangan, dari yang muda hingga orangtua. Namun, akhir-akhir ini, kalangan muda/remaja mulai sedikit hadir dalam majelis ilmu tersebut, dan mereka lebih memilih untuk bergaul dengan teman-temannya ditempat tongkorongan. Melihat hal tersebut, upaya orangtua sangatlah penting dalam meningkatkan kembali minat remaja untuk mengikuti kajian-kajian agama yang akan sangat berguna bagi mereka. Permasalahan inilah yang kemudian membuat peneliti tertarik untuk mengadakan penelitian yang bertujuan untuk mengetahui upaya-upaya apa saja yang dilakukan oleh orangtua untuk meningkatkan minat remaja dalam mengikuti kajian dimajlis ilmu di Masjid Nurul Iman Desa Payabenua tersebut dan diharapkan bisa menjadi gambaran ataupun pengetahuan bagi orangtua dalam mendidik dan meningkatkan minat belajar -anak meraka khususnya dalam mempelajari ilmu agama. Penelitian ini merupakan penelitian kualitatif deskriptif dengan jenis penelitian lapangan (field research). Teknik pengumpulan data dalam penelitian ini yaitu dengan cara observasi, wawancara, dan dokumentasi dimana setelah semua data terkumpul selanjutnya akan direduksi, disajikan, dianalisis dan kemudian disimpulkan untuk memperoleh informasi yang tepat. Hasil penelitian ini menunjukkan bahwa upaya-upaya yang dilakukan orangtua untuk meningkatkan minat anak remaja mereka dalam mengikuti kajian di majelis ilmu di Masjid Nurul Iman Desa Payabenua yaitu dengan memberikan arahan kepada anak, memberikan dorongan (motivasi), memberikan ketegasan dalam bentuk pembiasaan dan dengan memberikan hukuman ataupun hadiah. Hal tersebut dilakukan dikarenakan orang tua memiliki tangung jawab besar dalam membimbing dan mengarahkan anak-anaknya supaya lebih bisa memanfaat waktu dengan sebaik-baiknya dan juga supaya menjadi anak yang baik, pandai dan berguna bagi semua orang terutama dalam menanamkan nilai-nilai kepribadian yang berlandaskan agama islam.
\end{abstract}

\section{ABSTRACT}

In Payabenua village, there are several science assemblies, one of which is a science council which is held at the Nurul Iman Mosque every Monday night. The recitation was initially attended by several groups, from young people to the elderly. However, lately, young people / adolescents have started to attend a little of these knowledge assemblies, and they prefer to hang out with their friends at the barge shop. Seeing this, parents' efforts are very important in increasing the interest of adolescents to take part in religious studies which will be very useful for them. This problem is what then makes researchers interested in conducting research that aims to find out what efforts are made by parents to increase adolescent interest in participating in scientific studies at the Nurul Iman Mosque in Payabenua Village and it is hoped that it can become a description or knowledge for parents in educating. and increase their children's interest in learning, especially in studying religion. This research is a descriptive qualitative research with the type of field research (field research). Data collection techniques in this research are by means of observation, interviews, and documentation where after all the data is collected, it will be reduced, presented, analyzed and then concluded 
to obtain the right information. The results of this study indicate that the efforts made by parents to increase the interest of their teenagers in participating in studies in the science council at the Nurul Iman Mosque, Payabenua Village, namely by giving directions to children, providing encouragement (motivation), providing assertiveness in the form of habituation and by providing punishment or reward. This is done because parents have a big responsibility in guiding and directing their children so that they can make the best use of their time and also to become good, smart and useful children for everyone, especially in instilling personality values based on religion of Islam.

\section{Koresponden:}

Randu Abdi Cahyadi

Email: randuabdi7@gmail.com

\section{Pendahuluan}

Dalam kehidupan sehari-hari, setiap individu atau manusia saling berhubungan sosial dengan individu lainnya atau kelompok tertentu. Hubungan sosial yang dilakukan antar individu maupun antar kelompok tersebut sering dikenal dengan istilah interaksi sosial. Interaksi yang terjadi antara individu atau kelompok tersebut akan mengalami perkembangan dan membentuk suatu pola hubungan yang akan menjadi suatu sistem sosial dalam masyarakat yang disebut dengan proses sosial. Suatu hubungan sosial antar individu atau kelompok dalam suatu masyarakat salah satunya adalah melalui Majelis Ilmu atau Majelis Ta'lim. Majelis Ilmu ini maksudnya adalah tempat berkumpulnya individu dengan individu lainnya yang membentuk suatu kelompok yang mempelajari suatu ilmu yaitu ilmu terkait agama Islam (Bezlina, 2013).

Secara istilah Majelis Ilmu adalah lembaga pendidikan non formal Islam yang memiliki kurikulum sendiri atau aturan sendiri, yang diselenggarakan secara berkala dan teratur yang diikuti oleh banyak orang (jama'ah) dengan tujuan untuk membina dan mengembangkan hubungan yang santun dan serasi antara manusia dengan Allah SWT, manusia dengan manusia, serta manusia dengan lingkungannya dalam rangka membina masyarakat yang bertaqwa kepada Allah SWT (Suprayitno, 2019). Di desa Payabenua sendiri terdapat majelis Ilmu atau yang lebih dikenal di masyarakat yakni Majelis Ta'lim atau suatu kelompok yang melakukan pengajian ilmu agama Islam. Adapun salah satu Majelis Ilmu (pengajian) ini terdapat di Masjid Nurul Iman desa Payabenua. Majelis Ilmu di Masjid Nurul Iman ini bersifat umum yang dihadiri oleh tokoh agama maupun masyarakat umum baik laki-laki maupun perempuan di desa tersebut. Sedangkan Majelis Ta'lim yang dilakukan di desa Payabenua mayoritasnya hanya dihadiri oleh ibu-ibu atau kaum perempuan saja.

Di desa Payabenua sendiri banyak terdapat tempat pengajian yang diadakan hampir setiap malam, kecuali malam jum'at saja yang biasa dikenal dengan pengajian pesantren malam. Akan tetapi, dalam penelitian ini peneliti tertarik melakukan penelitian di Majelis Ilmu Masjid Nurul Iman yang diadakan seminggu sekali yaitu setiap malam senin. Pengajian Majelis Ilmu di Masjid Nurul Iman ini hanya diikuti atau dihadiri oleh tokoh agama yaitu bapak-bapak dan ibu-ibu saja, padahal sebelumnya remaja atau pemuda-pemudi didesa ini sering mengikut sertakan diri di setiap kajian Majelis Ilmu di Masjid Nurul Iman. Akan tetapi, semakin hari semakin berkurang minat remaja atau pemuda-pemudi dalam mengikuti kajian di Majelis Ilmu tersebut.

Berdasarkan hasil observasi yang dilakukan terhadap para remaja yang kurang berminat dalam mengikuti kajian di majelis ilmu ini yaitu dikarenakan remaja tersebut lebih memilih bergaul di tempat tongkrongan dengan teman-temannya. Hal lainnya yaitu dikarenakan tidak adanya kewajiban untuk mengikuti kajian di majelis ilmu tersebut baik dari desa ataupaun dari tempat mereka sekolah (belajar) dan juga dikarenakan yang mengikuti kajian majelis ilmu itu hanya bapak-bapak dan ibu-ibu (tidak ada teman yang seumuran dengan mereka). Adapun remaja yang peneliti maksud disini yaitu remaja yang putus sekolah dan remaja yang sekolah formalnya di luar desa Payabenua seperti remaja yang sekolahnya di sekolah umum misalnya di SMP/SMA. Sementara itu remaja di desa Payabenua yang sekolahnya di 
MTs/MA di desa Payabenua sendiri pada setiap malam harinya mereka mengikuti pengajian wajib yang diselenggarakan oleh pihak sekolah MTs/MA tersebut.

Dalam masalah seperti ini upaya orang tua sangatlah penting untuk meningkatkan minat mereka dalam mengikuti kajian-kajian tentang agama Islam yang berguna untuk masa depan mereka yang berkah baik di dunia dan akhirat kelak. Dengan berdasarkan latar belakang masalah ini peneliti mengangkat judul penelitian yaitu "Upaya Orang Tua Untuk Meningkatkan Minat Remaja Dalam Mengikuti Kajian Majelis Ilmu di Masjid Nurul Iman Desa Payabenua". Dengan penelitian ini, peneliti berharap dapat mengetahui upaya-upaya apa saja yang dilakukan oleh orangtua untuk meningkatkan minat remaja dalam mengikuti kajian di majlis ilmu di Masjid Nurul Iman Desa Payabenua tersebut. Penelitian ini juga diharapkan bisa menjadi gambaran ataupun pengetahuan bagi orangtua dalam mendidik dan meningkatkan minat belajar atau mengaji anak-anak meraka khususnya dalam menuntut ilmu agama yang sangat berguna di kemudian hari.

\section{Metode}

Jenis penelitian yang digunakan dalam penelitian ini yaitu jenis penelitian lapangan (field research), Hal ini dikarenakan data penelitian yang diperlukan dalam penyusunan karya ilmiah ini diperoleh dari lapangan. Penelitian ini dilakukan di Majelis Ilmu Masjid Nurul Iman Desa Payabenua Kecamatan Mendo Barat Kabupaten Bangka. Sementara untuk waktu penelitian ini yaitu dimulai dari tanggal 20 oktober 2020 dimana telah dimulainya kegiatan KKN-DR. Berdasarkan jenis data yang dikumpulkan, maka metode yang digunakan dalam penelitian ini yaitu metode penelitian kualitatif deskriftif. Menurut Sugiyono dalam bukunya dikatakan bahwa penelitian kualitatif deskriptif ini yaitu penelitian yang memandang objek sebagai sesuatu yang dinamis, hasil kontruksi pemikiran dan interpretasi terhadap gejala yang diamati, secara uutuh (holistic), karena setiap aspek dari objek itu mempunyai satu kesatuan yang tidak dapat dipisahkan (Sugiyono, 2007).

Dalam penelitian kualitatif deskriptif yang peneliti lakukan ini, peneliti akan memaparkan upayaupaya yang dilakukan oleh orang tua untuk meningkatkan minat remaja dalam mengikuti kajian majlis ilmu di Masjid Nurul Iman Desa Payabenua. Untuk pengumpulan data penelitian dilakukan dengan cara observasi, wawancara, dan dokumentasi dengan para orangtua. Kemudian data yang telah terkumpul akan direduksi, disajikan, dianalisis dan kemudian disimpulkan untuk memperoleh informasi yang tepat.

\section{Hasil dan Pembahasan}

\section{Upaya Orang Tua}

Orang Tua merupakan setiap orang yang bertanggung jawab dalam suatu keluarga atau rumah tangga yang dalam kehidupan sehari-hari lazim disebut dengan Bapak dan Ibu yang dimana mereka memegang peranan penting dalam keberlangsungan hidup rumah tangga atau keluarga. Orang tua memiliki kedudukan penting dalam membimbing dan mengarahkan anak-anaknya guna menjadi anak yang baik, pandai dan berguna bagi semua orang terutama dalam menanamkan nilai-nilai kepribadian muslim. Dengan demikian pengetahuan orang tua tentang pendidikan agama Islam sangat mempengaruhi bagi pendidikan akhlak, karena orang tua adalah madrasah pertama bagi anak-anaknya (Candra, 2019).

Orang tua juga diartikan sebagai mitra kerja yang utama bagi guru anaknya, bahkan sebagai orang tua mereka mempunyai berbagai peran pilihan yaitu orang tua sebagai pelajar, orang tua sebagai relawan, orang tua sebagai pembuat keputusan, dan lain-lain. Al-Qur'an mengatur urusan rumah tangga dan menegakkannya berdasarkan manhaj Islami. Itu sebabnya orang tua dituntut harus mampu memainkan peran dan fungsi sebaik mungkin agar anak tumbuh dan berkembang berdasarkan pola asuh yang baik dan benar (Putra, 2020). Adapun dalam Qs. At-Tahrim ayat 6 dijelaskan bahwa Islam memerintahkan agar para orang tua berlaku sebagai kepala dan pemimpin serta bertanggung jawab dalam hal pendidikan bagi keluarganya (Hakim, 2010).

\section{Bentuk-Bentuk Upaya Orang Tua Terhadap Anak}

Dalam mendidik anak hal yang sebaiknya diajarkan orang tua pertama kali yaitu mengajarkan kebaikan dengan memberikannya kasih sayang serta mengajarinya berhubungan baik dengan orang lain. Ini dilakukan agar kebaikan menjadi prinsip kehidupan bagi anak kedepannya sehingga anak tidak mudah menyimpang dan melakukan hal-hal negatif. Adapaun bentuk-bentuk upaya orang tua terhadap anaknya jika rincikan yaitu pertama, dapat berupa bimbingan dalam belajar seperti mendidik akan kesabaran dan bijaksana. Dan kedua, melakukan pengawasan terhadap anak dapat berupa memberikan dorongan (motivasi) kepada anak dalam hal minat bejar, melakukan pembiasaan akan hal-hal yang positif ataupun dengan pemberian hadiah atau hukuman (Subhan, 2019). 


\section{Minat Mengaji}

Minat merupakan kecenderungan jiwa yang tetap akan sesuatu hal yang berharga bagi seseorang atau bearti sesuai dengan kebutuhannya. Minat pada dasarnya merupakan penerimaan akan suatu hubungan antar diri sendiri dengan sesuatu diluar diri. Jika semakin kuat atau dekat hubungan tersebut, maka minat pun semakin besar (Ngalimu Dkk, 2016). Minat juga merupakan sebuah dorongan yang menyebabkan terikatnya perhatian seorang individu terhadap objek tertentu misalnya pekerjaan, pelajaran, benda, dan orang. Minat tersebut berhubungan dengan dengan aspek kognitif, afektif, dan motorik dan merupakan sumber motivasi untuk melakukan sesuatu yang diinginkan (Zahya, 2013).

Sementara mengaji dalam kamus bahasa Indonesia memiliki beberapa arti, yaitu: mendaras membaca Al-Qur'an, belajar membaca tulisan Arab, atau mempelajari ilmu agama (Indra, 2014). Dari hal dapat disimpulkan bahwa minat mengaji merupakan keinginan hati dari sesorang individu untuk mempelajari ilmu agama secara mendalam dengan giat sehingga membuat dirinya rajin mengikuti kegiatan kajian tentang ilmu agama.

4. Upaya Orang Tua Untuk Meningkatkan Minat Remaja Dalam Mengkuti Kajian Di Majelis Ilmu

Dari hasil penelitian yang penulis lakukan yakni mengenai upaya-upaya orang tua untuk meningkat minat remaja dalam mengikuti kajian di majelis ilmu Masjid Nurul Iman Desa Payabenua dapat dijelaskan sebagai berikut:

\section{a. Memberikan arahan kepada anak}

Masa remaja merupakan masa dimana anak selalu merasa selalu ingin tahu (penasaran) yang berlebihan terhadap hal-hal yang mereka anggap baru. Hal ini tidak jarang menyebabkan anak terjerumus kedalam pergaulan yang bersifat negatif. Melalui adanya kegiatan pengajian yang diadakan di majelis ilmu di Masjid Nurul Iman Desa Payabenua ataupun yang diadakan di tempat mereka sekolah orangtua berpendapat bahwa hal tersebut sangatlah baik untuk anak seusia mereka dikarenakan akan sangat berguna di saat mereka dewasa nanti. Adapaun upaya pertama yang dilakukan orang tua untuk meningkat minat mereka dalam mengikuti kajian dimajelis ilmu tersebut yakni dengan memberikan arahan kepada anak. Arahan tersebut berupa nasihat kepada anak supaya bisa memanfaatkan waktu muda untuk belajar ataupun memberikan penjelasan betapa pentingnya mempelajari ilmu agama yang sangat berguna dimasa depan nantinya.

Hal tersebut sangat sejalan dengan apa yang dilakukan oleh ibu Nursidah. Beliau mengatakan bahwa cara yang mereka lakukan selaku orang tua dari anaknya yang masih berusia remaja yaitu dengan selalu memberikan arahan berupa nasihat kepada anak mereka. Nasihat itu berupa teguran tentang kasus anak-anak yang tidak mau mengikuti kajian di majelis ilmu yang pernah terjadi sebelumnya yang membuat anak-anak tersebut menyimpang dan meresahkan masyarakat. Dimana hal semacam itu dikarenakan kurangnya ditanamkan ajaran agama Islam dalam diri mereka. Selain teguran seperti diatas, ibu Nursidah juga memberikan nasihat kepada anaknya bahwa Desa Payabenua dikenal dengan sebutan Desa Al-Qur'an. Dimana nama desa tersebut sudah dikenal baik, jadi generasi penerus ajaran agama Islam terutama anak remaja didesa tersebut juga harus baik untuk menebarkan kebaikan dengan cara mengajarkan kembali ilmu yang didapatkan untuk generasi selanjutnya pada kegiatan pengajian Majelis Ilmu.

\section{b. Memberikan dorongan (motivasi)}

Hal kedua yang dilakukan orang tua untuk meningkatkan minat remaja dalam mengikuti kajian dimajelis ilmu di Masjid Nurul Iman Desa Payabenua yakni dengan memberikan dorongan (motivasi) kepada anak mereka. Hal ini dilakukan supaya anak semakin berminat dalam mengikuti kajian di majelis ilmu yang diadakan. Dorongan (motivasi) yang biasanya diberikan orang tua yaitu berupa orangtua menjadi contoh teladan yang baik ataupun berupa kisah-kisah atau cerita para tokoh agama di Desa Payabenua terdahulu yang sangat pandai dan semangat dalam mempelajari ilmu agama. Hal ini seperti yang dilakukan oleh Bapak Azim yang memberikan motivasi kepada anak-anaknya melalui cerita tentang salah seorang ulama terdahalu yang berasal dari desa Payabenua yang menuntut ilmu agama sampai ke tanah suci Makkah dan menetap disana beberapa tahun demi menuntut ilmu agama islam. Beliau mengatakan bahwa anak mereka sangat senang jika diceritakan hal-hal semacam ini dan mereka akan termotivasi dengan sendirinya untuk menuntut dan mengikuti kajian-kajian di majelis ilmu yang diselenggarakan. 


\section{c. Memberikan ketegasan dalam bentuk pembiasaan}

Hal selanjutnya yang biasa dilakukan oleh orangtua untuk meningkatkan minat remaja dalam mengikuti kajian dimajelis ilmu di Masjid Nurul Iman Desa Payabenua yaitu dengan memberikan ketegasan dalam bentuk pembiasaan kepada anak. Ketegasan dalam bentuk pembiasaan ini yaitu berupa pemaksaan secara halus agar anak mau mengikuti kajian di majelis ilmu tersebut. Hal ini dirasa orang tua sangatlah efektif dikarenakan jika si anak mula-mulanya diberi paksaan untuk mengikuti kajian di majelis ilmu sehingga nantinya lambat laun mereka akan terbiasa dengan sendirinya dan akan sulit untuk meninggalkan kebiasaan tersebut.

Hal ini seperti yang dilakukan oleh Ahmad Baidowi yang mengatakan bahwa mereka selalu memberikan ketegasan kepada anak mereka dengan cara menjadwalkan kajian majelis ilmu yang diadakan setiap malam senin, dengan dibuatnya jadwal kajian secara rutin maka anak akan terbiasa mengikuti kajian majelis ilmu tersebut. Dan tidak lupa peran orang tua sangatlah penting, dimana jika orang tua menginginkan anak untuk rutin dalam mengikuti kajian majelis ilmu maka kebiasaan mengaji tersebut harus di mulai dari orang tua terlebih dulu. Mendidik anak sedari kecil dapat memberikan dampak yang luar biasa nantinya. Pola pembiasaan sejak kecil memberikan dampak kepada anak yaitu memiliki keterampilan serta kepribadian yang baik dan berkualitas, berakhlak mulia, kuat secara fisik dan mental. Karena suatu perilaku yang dilakukan secara terus menerus akan menjadi suatu kebiasaan.

\section{d. Memberikan hukuman ataupun hadiah}

Hal terakhir yang biasa dilakukan oleh orangtua untuk meningkatkan minat remaja dalam mengikuti kajian dimajelis ilmu di Masjid Nurul Iman Desa Payabenua yaitu dengan memberikan hukuman ataupun hadiah. Pemberian hukuman diberikan jika anak terus menolak untuk mengikuti kajian dimajelis ilmu dan lebih memilih untuk berkumpul dan menghabiskan waktu dengan temantemannya. Hukuman yang diberikan ini biasanya dalam bentuk teguran ataupun berupa tindakan yang mendidik. Adapun pemberian hadiah dilakukan jika si anak selalu giat dan semangat untuk mengkuti kajian di majelis ilmu tersebut. Pemberian hadiah ini bertujuan supaya si anak tidak merasa bosan dan terus bersemangat untuk belajar dan mengikuti kajian dimajelis ilmu tersebut.

Hal ini juga dilakukan oleh Bapak Amin yang mana beliau sendiri merupakan salah seorang yang paham mengenai ajaran agama. Adapaun hal yang dilakukan beliau terhadap anaknya yang kurang berminat untuk mengikuti kajian Majelis Ilmu di Masjid Nurul Iman yakni dengan memberikan pukulan-pukulan kecil untuk memberikan efek jera kepada anak, tidak memperbolehkan nongkrong dengan teman-temannya, dan memberikan batasan menggunakan android. Sedangkan hadiah yang biasa beliau berikan kepada anaknya jika anaknya rajin mengikuti kajian di majelis ilmu yaitu berupa barang yang membuat anak semangat untuk mengikuti kajian tersebut, seperti memberikan sarung baru, kopiah, kitab agama seperti Al-Quran terjemahan berwarna, dan memberikan barang yang sangat diinginkan oleh anaknya.

\section{Kesimpulan}

Berdasarkan pemaparan di atas dapat penulis simpulkan bahwa minat mengaji merupakan keinginan hati dari sesorang individu untuk mempelajari ilmu agama secara lebih mendalam dengan giat sehingga membuat dirinya rajin mengikuti setiap kajian tentang ilmu agama. Adapun upaya-upaya yang dilakukan orangtua untuk meningkatkan minat anak remaja mereka dalam mengikuti kajian di majelis ilmu di Desa Payabenua yaitu dengan memberikan arahan kepada anak, memberikan dorongan (motivasi), memberikan ketegasan dalam bentuk pembiasaan dan dengan memberikan hukuman ataupun hadiah. Hal ini dilakukan karena orang tua memiliki tangung jawab besar dalam membimbing dan mengarahkan anakanaknya supaya lebih memanfaat waktu dengan sebaik-baiknya dan juga supaya menjadi anak yang baik, pandai dan berguna bagi semua orang terutama dalam menanamkan nilai-nilai kepribadian berlandaskan agama islam.

\section{Referensi}

Bezlina, S. A. (2013). Peranan Majelis Ta'lim Riyadus SholihahTerhadap Peningkatan Kualitas Pendidikan Keluarga. Bandung. Retrieved from upi: repository.upi.edu

Candra, A. (2019). Upaya Orang Tua Dalam Meningkatkan Motivasi Belajar Agama Pada Anak di TPQ Desa 
Tanjung Aur kec Sinding Beliti Kab. Rejang Lebong. IAIN Curup, Curup.

Hakim, N. (2010). Kerjasama wali murid dengan guru dalam meningkatkan minat belajar siswa pada mata pelajaran pendidikan agama Islam di SMP Negeri 2 Kedungwaru Tulungagung.

Indra, D. (2014). Pelaksanaan Manajemen Program Gerakan Masyarakat Magrib Mengaji di Provinsi Sumatra Barat. Jurnal AL-FIKRAH, 11(2).

Ngalimu Dkk. (2016). Strategi Dan Model Pembelajaran. Yogyaarta: Aswaja Pressindo.

Putra, A. (2020). Pola Asuh Orang Tua Dalam Menanamkan Minat Baca Al-Qur'an Anak Di Desa Kota Agung Kecamatan Air Besi Kabupaten Bengkulu Utara. IAIN Bengkulu.

Subhan, dkk. (2019). Peran Orangtua Dalam Menumbuhkan Minat Anak Baca Al-Qur'an Di Desa Teluk Rendah Ilir Kecamatan Tebo Ilir Kabupaten Tebo. UIN Sulthan Thaha Saifuddin.

Sugiyono. (2007). Metode Penelitian Pendidikan, Pendekatan Kualitatif, Kuantitatif, dan R\&D. Bandung: Alfabeta.

Suprayitno, K. (2019). Peran Majelis Ta'lim Dalam Meningkatkan Pendidikan Nilai-nilai Agama Islam dan Ukhuwah Islamiyah. Retrieved from Jurnal eprints.umpo.ac.id.

Zahya, yudrik. (2013). Psikologi Perkembangan. Jakarta: Prenada Media Group. 